\title{
EFEKTIVITAS PEMBELAJARAN KOOPERATIF DENGAN MENGGUNAKAN MODUL
}

\author{
Tetty Natalia Sipayung ${ }^{1)}$, Sinta Dameria Simanjuntak ${ }^{2)}$ \\ ${ }^{1,2)}$ Pendidikan Matematika Universitas Katolik Santo Thomas \\ Email: tettysipayung83@gmail.com ${ }^{1)}$; sh1_nta@yahoo.com ${ }^{2)}$
}

\begin{abstract}
The aims of this research are to determine the effectiveness of cooperative learning by using modules. The type of this research is quantitative research by descriptive method. This research consisting of experiment class and control class. Students in the experimental class are taught by applying cooperative learning using modules while students in control classes are taught by applying conventional learning without modules. The results suggest that cooperative learning using modules is effective. This can be seen from the average percentage of the students minimum achievement in the control class is $54.92 \%$ while in the experimental class is $73.17 \%$. Student activity in the experimental class is excellent with an average score is 4.05 whereas in the control class is good with an average score is 3.7. The ability of teachers in managing learning in the experimental class is very good with an average score is 4.66 whereas in the control class is good with the average score is 4. Thus cooperative learning using the module is effective.
\end{abstract}

Keywords: cooperative learning, effectiveness, module

\section{PENDAHULUAN}

Guru mempunyai peranan penting dalam usaha memperbaiki mutu pendidikan. Seorang guru dituntut untuk dapat mengembangkan program pembelajaran yang optimal sehingga terwujud proses pembelajaran yang efektif dan efisien khususnya dalam pembelajaran matematika.

Menurut Fathani (Hendriana dkk, 2014: 10) salah satu ciri pembelajaran matematika adalah bukan hanya menunjukkan konsep-konsep atau rumus-rumus matematika saja, melainkan juga menunjukkan tentang aplikasi dan manfaatnya dalam kehidupan sehari-hari, yang tentunya dalam menginformasikannya disesuaikan dengan tingkatan atau jenjang sekolah siswa sehingga para siswa diharapkan akan menjadi tertarik dan tertantang untuk berusaha memahami matematika lebih dalam. Untuk mewujudkan proses pembelajaran matematika yang efektif dan efisien maka diperlukan pengetahuan dan kemampuan guru dalam mendesain pembelajaran yang efektif. Pengetahuan yang dimaksud adalah pengenalan akan model pembelajaran inovatif. Hampir sebagian besar guru belum mengetahui variasi model pembelajaran kooperatif dan penerapannya.

Pembelajaran kooperatif adalah pembelajaran secara berkelompok dan tidak menekankan pada situasi pengalaman siswa. Pada pembelajaran kooperatif, siswa belajar dalam kelompok-kelompok kecil yang terdiri dari 4-6 siswa yang sederajat tetapi heterogen, kemampuan, jenis kelamin, 
suku atau ras, dan satu sama lain saling membantu. Tujuan dibentuknya kelompok tersebut adalah untuk memberikan kesempatan kepada semua siswa untuk dapat terlibat secara aktif dalam proses berpikir dan kegiatan belajar. Selama bekerja dalam kelompok, tugas anggota kelompok adalah mencapai ketuntasan materi yang disajikan guru, dan saling membantu teman sekelompoknya untuk mencapai ketuntasan belajar (Trianto, 2009:56). Model pembelajaran kooperatif merupakan bagian dari pembelajaran inovatif. Variasi model pembelajaran kooperatif meliputi: Student Teams Achievement Division (STAD), Numbered Head Together (NHT), Think Pair Share (TPS), dan Jigsaw.

Selain guru dituntut mampu mewujudkan pembelajaran yang efektif, guru juga diharapkan dapat membuat bahan ajar sendiri. Kenyataannya sebagian besar guru belum mampu menyusun bahan ajar sendiri dengan menggunakan modul. Hal tersebut dikarenakan guru kurang memahami mekanisme dan teknis dalam menyusun modul.

Menurut Depdiknas (dalam Gazali, 2016), bahan ajar merupakan seperangkat materi yang disusun secara sistematis baik tertulis maupun tidak sehingga tercipta lingkungan atau suasana yang memungkinkan siswa untuk belajar. Bahan ajar yang diharapkan adalah bahan ajar yang disusun oleh guru itu sendiri karena guru adalah orang yang ahli dalam praktek lapangan yang lebih paham kondisi di lapangan bahkan karakteristik dan tingkat kemampuan siswa di kelas. Salah satu contoh bahan ajar yang dapat didesain guru adalah modul.

Modul merupakan bahan ajar yang disusun secara sistematis dan menarik yang mencakup isi materi, metode, dan evaluasi yang dapat digunakan secara mandiri. Menurut Prastowo (dalam Tjiptiany dkk, 2016) pembelajaran dengan menggunakan modul bertujuan: (1) siswa mampu belajar secara mandiri atau dengan bantuan guru seminimal mungkin, (2) peran guru tidak mendominasi dan tidak otoriter dalam pembelajaran, (3) melatih kejujuran siswa, (4) mengakomodasi berbagai tingkat dan kecepatan belajar siswa, dan (5) siswa dapat mengukur sendiri tingkat penguasaan materi yang dipelajari.

Berdasarkan penjelasan tersebut, maka dilaksanakan penelitian untuk mengetahui efektivitas pembelajaran kooperatif dengan menggunakan modul.

\section{METODE PENELITIAN}

Jenis penelitian ini merupakan penelitian kuantitatif dengan menerapkan variasi model pembelajaran kooperatif dengan menggunakan modul. Untuk mengetahui efektivitas variasi pembelajaran kooperatif dengan menggunakan modul yang dianalisis berdasarkan hasil belajar siswa, aktivitas siswa, dan kemampuan guru dalam mengelola pembelajaran.

Penelitian ini menggunakan metode deskriptif kualitatif dan kuantitatif. Metode deskriptif kualitatif digunakan untuk menggambarkan kondisi yang sebenarnya tentang proses pembelajaran yang diterapkan di kelas, sedangkan metode kuantitatif digunakan untuk menganalisis data berupa angkaangka.

Penelitian ini dilaksanakan di SMA Nusantara Jln. Tengku Raja Muda No.1 Lubuk Pakam. Populasi dari penelitian ini adalah seluruh siswa kelas X SMA Nusantara Lubuk Pakam Tahun Ajaran 2017/2018. Sedangkan yang menjadi sampel penelitian ini adalah siswa kelas XMIA-1 sebagai kelas eksperimen yang dibelajarkan dengan 
menggunakan modul matematika dengan menerapkan variasi pembelajaran kooperatif dan siswa kelas X MIA-4, X IPS-2, X IPS-3 merupakan kelas kontrol yang dibelajarkan tanpa menggunakan modul dengan menerapkan pembelajaran konvensional.

Instrumen yang digunakan dalam penelitian ini adalah tes dan lembar observasi. Tes digunakan untuk mengetahui hasil belajar siswa. Sementara lembar observasi digunakan untuk mengetahui aktivitas siswa dan kemampuan guru dalam mengelola pembelajaran.

Teknik analisa data yang digunakan dalam penelitian ini adalah (1) analisis instrumen hasil belajar yang terdiri dari validitas dan reabilitas tes, (2) analisis data hasil belajar yang diperoleh dari hasil tes tertulis berbentuk uraian yang dianalisis berdasarkan Kriteria Ketuntasan Minimal (KKM), (3) analisis data observasi aktivitas siswa, dan kemampuan guru dalam mengelola pembelajaran.

\section{HASIL PENELITIAN DAN PEMBAHASAN}

Sebuah pembelajaran dikatakan efektif jika tingkat keberhasilan yang dicapai sesuai dengan tujuan pembelajaran yang telah direncanakan, hasil belajar siswa sesuai dengan kriteria dan ketuntasan minimal yang ditetapkan, aktivitas siswa berada dalam kategori aktif, dan kemampuan guru dalam mengelola pembelajaran berada dalam kategori baik. Untuk menganalisis efektivitas pembelajaran pada pembelajaran kooperatif dengan menggunakan modul akan ditelaah berdasarkan kriteria atau indikator yang telah dijelaskan tersebut.

\section{Hasil Belajar Siswa}

Menurut Susanto (2013: 5) hasil belajar adalah kemampuan yang diperoleh anak setelaah melalui kegiatan belajar. Instrumen yang digunakan untuk mengukur hasil belajar adalah tes uji kemampuan siswa dalam bentuk soal uraian.

Tes uji kemampuan yang digunakan terdiri atas 4 kelompok tes yaitu tes uji kemampuan 1, 2, 3, dan 4 . Sebelum tes uji kemampuan digunakan untuk mengukur hasil belajar siswa terlebih dahulu dilakukan uji kelayakan terhadap tes uji kemampuan. Uji kelayakan yang digunakan adalah uji validitas dan reliabilitas. Uji validitas yang dianalisis terdiri atas uji validitas unsur pembangun dan validasi ahli. Berdasarkan hasil uji coba diperoleh uji validitas unsur pembangun dan reablitas tes uji kemampuan 1 dengan 5 butir soal adalah valid dan reliabel, tes uji kemampuan 2 yang terdiri dari 3 soal adalah valid dan reliabel. Tes uji kemampuan 3 yang terdiri dari 3 soal adalah valid dan reliabel, dan tes uji kemampuan 4 yang terdiri dari 2 soal adalah valid dan reliabel.

Hasil validasi ahli yang terdiri dari dua orang ahli menunjukkan bahwa tes uji kemampuan adalah valid dengan keterangan tanpa revisi. Dengan demikian, tes uji kemampuan 1, 2, 3, dan 4 layak digunakan untuk mengukur hasil belajar siswa.

Tes yang telah diuji kelayakannya digunakan untuk mengukur hasil belajar pada dua kelas yaitu kelas eksperimen dan kelas kontrol. Kelas eksperimen adalah kelas yang dibelajarkan dengan pembelajaran kooperatif dengan menggunakan modul. Sementara kelas kontrol adalah kelas yang dibelajarkan dengan pembelajaran konvensional tanpa modul. Variasi pembelajaran kooperatif yang digunakan adalah pembelajaran Student Teams Achievement Division (STAD), 
Numbered Head Together (NHT), Think Pair Share (TPS), dan Jigsaw.

Data yang diperoleh dari hasil penelitian akan dijelaskan berdasarkan hasil tes di kelas kontrol dan di kelas eksperimen. Hal ini dapat dilihat pada tabel berikut:

Tabel 1. Hasil Tes Kelas Eksperimen dan Kelas Kontrol

\begin{tabular}{|c|c|c|}
\hline \multirow{2}{*}{ Materi } & \multicolumn{2}{|c|}{ Persentase Siswa Yang Mencapai KKM } \\
\cline { 2 - 3 } & Kelas Eksperimen & Kelas Kontrol \\
\hline Materi ke-1 & 70,73 & 52,50 \\
\hline Materi ke-2 & 78,05 & 58,82 \\
\hline Materi ke-3 & 73,17 & 56,00 \\
\hline Materi ke-4 & 70,73 & 52,38 \\
\hline
\end{tabular}

$\begin{array}{ccc}\text { Kriteria Ketuntasan } & \text { Minimal } \\ (\mathrm{KKM}) \quad \text { untuk mata pelajaran }\end{array}$ matematika kelas X SMA Tahun Ajaran 2017/2018 yang ditetapkan di SMA Nusantara Lubuk Pakam adalah 75. Berdasarkan tabel di atas maka dapat disimpulkan persentase rata-rata siswa yang memenuhi KKM pada kelas kontrol adalah 54,92\%, sedangkan pada kelas eksperimen adalah $73,17 \%$. Jadi berdasarkan tes hasil belajar disimpulkan bahwa pembelajaran kooperatif dengan menggunakan modul lebih efektif daripada pembelajaran konvensional tanpa menggunakan modul.

\section{Aktivitas Siswa}

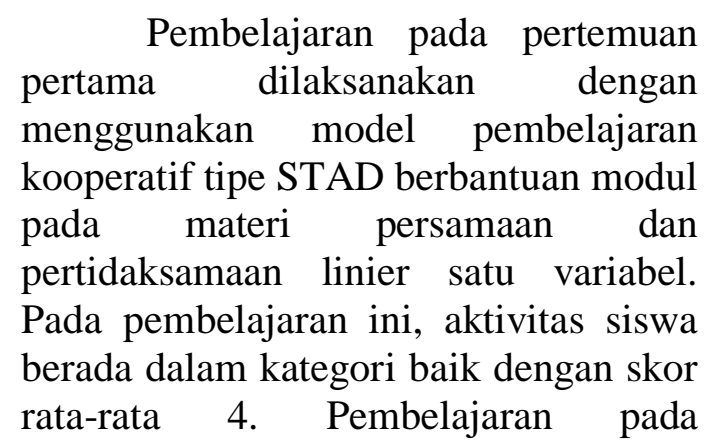

pertemuan kedua dilaksanakan dengan menggunakan model pembelajaran kooperatif tipe NHT dengan berbantuan modul pada materi persamaan nilai mutlak linier satu variabel. Pada pembelajaran ini, aktivitas siswa berada dalam kategori sangat baik dengan skor rata-rata 4,23. Pembelajaran pada pertemuan ketiga dilaksanakan dengan menggunakan model pembelajaran kooperatif tipe TPS berbantuan modul dengan materi pertidaksamaan nilai mutlak linier satu variabel. Pada pembelajaran ini, aktivitas siswa berada dalam kategori baik dengan skor ratarata 4. Pembelajaran pada pertemuan keempat dilaksanakan dengan menggunakan model pembelajaran kooperatif tipe Jigsaw berbantuan modulpada materi sistem persamaan linier tiga variabel. Pada pembelajaran ini, aktivitas siswa berada dalam kategori baik dengan skor rata-rata 4 . Hal ini dapat dilihat pada tabel 2 berikut: 
ISSN 2089-8703 (Print) Vol. 6, No. 3 (2017)

ISSN 2442-5419 (Online)

Tabel 2. Skor Rata-Rata Aktivitas Siswa

\begin{tabular}{|c|l|c|c|}
\hline $\begin{array}{c}\text { Pert. } \\
\text { ke- }\end{array}$ & \multicolumn{1}{|c|}{ Model Pembelajaran Kooperatif } & $\begin{array}{c}\text { Skor Rata-Rata } \\
\text { Aktivitas Siswa }\end{array}$ & Kriteria \\
\hline 1. & $\begin{array}{l}\text { Student Teams Achievement Division } \\
\text { (STAD) }\end{array}$ & 4 & Baik \\
\hline 2. & Numbered Head Together (NHT) & 4,23 & Sangat Baik \\
\hline 3. & Think Pair Share (TPS) & 4 & Baik \\
\hline 4. & Jigsaw & 4 & Baik \\
\hline
\end{tabular}

Dengan demikian dapat disimpulkan bahwa aktivitas siswa dengan menerapkan pembelajaran kooperatif dengan menggunakan modul adalah sangat baik dengan skor rata-rata 4,05. Sementara aktivitas siswa tanpa menggunakan modul dengan menerapkan pembelajaran konvensional adalah adalah baik dengan skor rata-rata 3,7 .

\section{Kemampuan Guru Dalam Mengelola Pembelajaran}

Pada umumnya, kegiatan pembelajaran dibagi atas 3 tahap. Ketiga tahap tersebut adalah tahap pendahuluan, inti, dan penutup. Kemampuan guru dalam mengelola pembelajaran pada ketiga tahap dalam pembelajaran kooperatif tipe STAD berbantuan modul adalah sangat baik dengan skor rata-rata 4,54. Kemampuan guru mengelola pembelajaran pada pembelajaran kooperatif tipe NHT berbantuan modul adalah sangat baik dengan skor rata-rata 4,64. Kemampuan guru dalam mengelola pembelajaran pada pembelajaran kooperatif tipe TPS berbantuan modul adalah sangat baik dengan skor rata-rata 4,64. Kemampuan guru dalam mengelola pembelajaran pada pembelajaran kooperatif tipe Jigsaw berbantuan modul adalah sangat baik dengan rata-rata 4,82 .

Tabel 3. Skor Rata-Rata Kemampuan Guru Dalam Mengelola Pembelajaran

\begin{tabular}{|c|l|c|c|}
\hline $\begin{array}{c}\text { Pert. } \\
\text { ke- }\end{array}$ & Model Pembelajaran Kooperatif & $\begin{array}{c}\text { Skor Rata-Rata } \\
\text { Kemampuan } \\
\text { Guru }\end{array}$ & Kriteria \\
\hline 1. & $\begin{array}{l}\text { Student Teams Achievement } \\
\text { Division (STAD) }\end{array}$ & 4,54 & Sangat Baik \\
\hline 2. & Numbered Head Together (NHT) & 4,64 & Sangat Baik \\
\hline 3. & Think Pair Share (TPS) & 4,64 & Sangat Baik \\
\hline 4. & Jigsaw & 4,82 & Sangat Baik \\
\hline
\end{tabular}

Berdasarkan table 3 di atas, maka secara keseluruhan dapat disimpulkan bahwa kemampuan guru dalam mengelola pembelajaran dengan menerapkan variasi model pembelajaran kooperatif dengan menggunakan modul adalah sangat baik dengan skor rata-rata 4,66. Sementara kemampuan guru dalam mengelola pembelajaran tanpa menggunakan modul dengan menerapkan pembelajaran konvensional adalah adalah baik dengan skor rata-rata 4.

\section{KESIMPULAN DAN SARAN}

Berdasarkan hasil penelitian dan pembahasan diperoleh kesimpulan bahwa pembelajaran kooperatif dengan menggunakan modul pada kelas $\mathrm{X}$ SMA adalah efektif. Hal ini terlihat dari 
persentase rata-rata siswa yang memenuhi KKM, aktivitas siswa, dan kemampuan guru dalam mengelola pembelajaran di kelas eksperimen lebih baik daripada di kelas kontrol. Pembelajaran di kelas eksperimen dengan menerapkan variasi model pembelajaran kooperatif dan menggunakan modul, sementara pembelajaran di kelas kontrol menerapkan pembelajaran konvensional dan tidak menggunakan modul.

Dengan demikian untuk meningkatkan efektivitas pembelajaran yang meliputi hasil belajar siswa, aktivitas siswa dan kemampuan guru mengelola pembelajaran disarankan sebaiknya guru menerapkan pembelajaran kooperatif dengan menggunakan modul.

\section{UCAPAN TERIMAKASIH}

Penulis mengucapkan terimakasih kepada Direktorat Jenderal Peenguatan Riset dan Pengembangan (DPRM) Kementerian Riset, Teknologi dan Pendidikan Tinggi Republik Indonesia atas kesempatan yang diberikan untuk melaksanakan penelitian ini dan sumbangan dana yang diberikan sehingga penelitian ini berjalan dengan baik. Selain daripada itu, penulis juga mengucapkan terimakasih kepada Ketua Lembaga Penelitian dan Pengabdian Kepada Masyarakat (LPPM) Universitas Katolik Santo Thomas atas dukungan yang diberikan kepada penulis.

\section{DAFTAR PUSTAKA}

Gazali, R. Y. 2016. Pengembangan Bahan Ajar Matematika Untuk Siswa SMP Berdasarkan Teori Belajar Ausubel. Pythagoras: Jurnal Pendidikan Matematika, Vol. 11. No. 2. Hal. 182-192.
Hendriana, H. dkk. 2014. Penilaian Pembelajaran Matematika. Bandung: PT. Refika Aditama.

Susanto, A. 2013. Teori Belajar dan Pembelajaran di Sekolah Dasar. Jakarta: Kencana.

Tjiptiany, E. N. dkk. 2016. Pengembangan Modul Pembelajaran Matematika Dengan Pendekatan Inkuiri Untuk Membantu Siswa SMA Kelas X Dalam Memahami Materi Peluang. Jurnal Pendidikan: Teori, Penelitian dan Pengembangan. Vol. 1. No. 10. Hal. 1938-1942.

Trianto. 2009. Mendesain Model Pembelajaran Inovatif-Progresif, Konsep, Landasan, dan Implementasinya Pada Kurikulum Tingkat Satuan Pendidikan (KTSP). Jakarta: Kencana. 